\title{
Moral distress: challenges for an autonomous nursing professional practice*
}

\author{
SOFRIMENTO MORAL: DESAFIOS PARA UMA PRÁTICA PROFISSIONAL DE \\ ENFERMAGEM AUTÔNOMA
}

\section{SUFRIMIENTO MORAL: DESAFÍOS PARA UNA PRÁCTICA PROFESIONAL DE ENFERMERÍA AUTÓNOMA}

\section{Edison Luiz Devos Barlem ${ }^{1}$,Valéria Lerch Lunardi ${ }^{2}$,Jamila Geri Tomaschewski ${ }^{3}$,Guilherme Lerch Lunardi ${ }^{4}$,Wilson Danilo Lunardi Filho ${ }^{5}$,Camila Rose Guadalupe Barcelos Schwonke ${ }^{6}$}

\begin{abstract}
Constantly experiencing limiting situations that hinder a professional practice coherent with its principles - of autonomy and advocacy of users' interests -, and often conditioned to experience moral distress, the nursing profession plays a prominent role in the current health model because it has the characteristic of managing the care rendered to users in a perspective of social inclusion, both in the basic health network and in hospitals. Aiming at carrying out a reflection on the nursing practice and the difficulties present in its work routine, and considering its characteristics as a profession, this article sought to make a reflection between the practice of nursing and the numerous moral challenges imposed by the routine, resulting, in many cases, in a value crisis that can reverberate directly on the quality of the service rendered, and in abandonment of the ideals of advocacy for users
\end{abstract}

\section{DESCRIPTORS}

Nursing

Professional practice

Ethics, nursing

Stress psychological

Health advocacy

\section{RESUMO}

O profissional de enfermagem apresenta um papel de destaque no atual modelo de saúde. Tem em como característica gerenciar os cuidados prestados aos usuários em uma perspectiva de inclusão social, tanto na rede básica, quanto nas instituições hospitalares. Entretanto, enfrenta constantemente limitações que dificultam o exercício profissional coerente com princípios de autonomia e advocacia pelos interesses dos usuários, o que muitas vezes o leva vivenciar o sofrimento moral. Com o objetivo de realizar uma reflexão sobre a prática de enfermagem e as dificuldades existentes no seu cotidiano de trabalho da enfermagem, considerando suas características como profissão, o presente artigo buscou realizar uma reflexão entre o fazer da enfermagem e os inúmeros desafios morais impostos pelo cotidiano, resultando, em muitos casos, em uma crise de valores que pode repercutir diretamente na qualidade do atendimento prestado e no abandono dos ideais de advocacia pelos usuários.

\author{
DESCRITORES \\ Enfermagem \\ Prática profissional \\ Ética em enfermagem \\ Estresse psicológico \\ Advocacia em saúde
}

\begin{abstract}
RESUMEN
El profesional de enfermería presenta un rol destacado en el actual modelo de salud. Adquiere la característica de administrar los cuidados brindados a los pacientes en una perspectiva de inclusión social, tanto en la red básica como en las instituciones hospitalarias. Sin embargo, enfrenta constantemente limitaciones que dificultan el ejercicio profesional coherente con principios de autonomía de abogar por los intereses de los pacientes, lo que muchas veces lo lleva a experimentar sufrimiento moral. Objetivando reflexionar acerca de la práctica de enfermería y considerando sus características profesionales, el presente artículo procuró realizar una reflexión entre el quehacer de enfermería y los innumerables desafíos morales impuestos por el día a día; resultando, a menudo, en una crisis de valores que puede tener repercusión directamente en la calidad de la atención brindada y en el abandono del ideal de abogar por el bienestar de los pacientes.
\end{abstract}

\section{DESCRIPTORES \\ Enfermería \\ Práctica profesional \\ Ética en enfermería \\ Estrés psicológico \\ Defensa de la salud}

\footnotetext{
*Extracted from the thesis "Reconfigurando o sofrimento moral na enfermagem: uma visão Foucaltiana", Post-Graduated of Nursing Program from Universidade Federal do Rio Grande, 2012. ${ }^{1} \mathrm{PhD}$ in Nursing. Professor from the Post-Graduated of Nursing Program from Universidade Federal do Rio Grande. Rio Grande, RS, Brazil. ebarlem@gmail.com ${ }^{2}$ Nurse. PhD in Nursing. Professor from the Post-Graduated of Nursing Program from Universidade Federal do Rio Grande. Scholarship Productivity from Conselho Nacional de Desenvolvimento Científico e Tecnológico (CNPq). Rio Grande, RS, Brazil. vlunardi@terra.com.br ${ }^{3}$ Nurse. Master's in Nursing. PhD Student from the Post-Graduated of Nursing Program from Universidade Federal do Rio Grande. Scholarship from Coordenação de Aperfeiçoamento de Pessoal de Nível Superior/Fundação de Amparo à Pesquisa do Estado do Rio Grande do Sul (CAPES/FAPERGS). Rio Grande, RS, Brazil. jamila_tomaschewski@hotmail.com ${ }^{4}$ Administrator. PhD in Administration. Professor from the Post-Graduated of Nursing Program from Universidade Federal do Rio Grande. Rio Grande, RS, Brazil. gllunardi@furg.br ${ }^{5}$ Nurse. PhD in Nursing. Professor from the PostGraduated of Nursing Program from Universidade Federal do Rio Grande. Scholarship Productivity from Conselho Nacional de Desenvolvimento Científico e Tecnológico (CNPq). Rio Grande, RS, Brazil. lunardifilho@terra.com.br ${ }^{6}$ Nurse. PhD in Nursing. Pelotas, RS, Brazil. kamila.enf@ig.com.br
}

$\begin{aligned} & \begin{array}{r}\text { Rev Esc Enferm USP } \\ 2013 ; 47(2): 506-10 \\ \text { www.ee.usp.br/reeusp/ }\end{array} \text { Recebido: } 27 / 07 / 2011 \\ & \text { Aprovado: } 11 / 07 / 2012\end{aligned}$




\section{INTRODUCTION}

Nursing professionals face every day a variety of moral problems ranging from those resulting from the growth in scientific and knowledge and technology, with the creation of new diagnostic equipment and new treatment modalities ${ }^{(1)}$, to conflicts caused by the way users can be treated by professionals, whether in the basic network or in hospital environments. When there are attempts to face conflicts, workers seem to be poorly answered in their requests, being often ignored by their leaders and heads, thus being insufficiently supported in the practice of their professional autonomy, and this may cause workers to feel angry, indignant, guilty, sad, hopeless, frustrated and impotent toward problems ${ }^{(2)}$.

Nursing workers experience moral problems and conflicts in trivialized situations in the work environments, which are taken as inseparable parts in the professional life. Some of these problems include lack of consent before procedures, elongation of life without worrying about its quality, inhuman or questionable professional practices, fragmented decisions and inequality in allocation of resources, especially those assigned to the nursing team itself ${ }^{(3)}$, which triggers in the workers a suffering recognized as moral distress.

Every day, in Brazil, thousands of nursing professionals working in health services might be experiencing those situations without understanding their consequences, without at least question what is hindering the autonomous professional practice, and without being able to fully practice their profession, often failing to defend the user's rights, without knowing how to cope with such contexts ${ }^{(3)}$.

In a mood of constant changes in health care, of organizational difficulties and of an intense value crisis, the defense of users has become the biggest challenge in the nursing practices ${ }^{(4)}$, demanding that nurses assume their roles, especially those linked to advocacy of users. It is impossible not to recognize the importance of nursing as a moral practice in its essence, which daily deals with issues of moral agency in the lives of people receiving its cares, which makes full use of the ability to think, act, and be responsible for actions not always easy to be adopted ${ }^{(5)}$.

These actions, which are related to other people's lives, may also be hampered by value conflicts that are not always explicated among the health team or with the users, and these are facts that, although not verbalized by nursing professionals, may still weaken them, by affecting their principles with loss of autonomy and difficulties in exercise of power ${ }^{(5)}$.
In health teams, the nursing professional's voices are muffled when it comes to express their moral preoccupations, bringing out questions about the morality of the cares provided. Thus, nursing professionals may present themselves impotent and in non-recognized experience of a process of moral distress, mainly as a result of the incongruence of their actions with their moral judgments, possibly suffering along with the users and their families. These events are used to strengthen their isolation and even the abandonment of the profession ${ }^{(4)}$.

This article aims at carrying out a reflection on the nursing practice and the difficulties present in its routine, considering the characteristics of the profession - toward care and advocacy of users -, with the confrontation of limitations for a professional practice coherent with its principles. Firstly, we are going to approach moral distress and its implications for nursing, followed by the rescue of the concept of advocacy of the user, and some possibilities for more autonomous and competent professional practices from the moral point of view.

\section{MORAL DISTRESS IN NURSING PRACTICE}

In the professional context of nursing, moral distress was firstly described in the 1980 's, being defined as the suffering resulting from the incoherence between the workers' actions and their personal conviction. The nursing professionals facing a moral problem acknowledge that a more specific action would be the best one to be adopted, however, they see it as something almost impossible to be implemented, and misjudgments, failures of conduct and even circumstances apart from their personal control may contribute to this situation ${ }^{(6-7)}$.

Three distinct categories of moral problems can be experimented: Moral Uncertainty, when the person recognizes a problem as an inadequate or incorrect situation, and questions himself; Moral Dilemma, when the person identifies to distinct courses to follow, but can only choose one; moral distress, situation in which the person know what is correct and what should be done, but it is not possible for him to follow his conscience $^{(6)}$.

Another applicable definition to moral distress is to consider it as a grievous feeling or psychological imbalance resulting from the acknowledgement of an ethically correct action that can't be adopted because of hurdles such as lack of time, managers' reluctance or a power structure that is able to inhibit a moral, political, institutional, or legal action ${ }^{(6-7)}$. When nurses and other health professionals face limitations in their capabilities for an autonomous 
practice, feeling forced to endanger their values and personal rules, they may experience moral distress ${ }^{(8-9)}$.

Despite the generalized preoccupations of researchers of the health field and their studies about work in care environments throughout the last two decades, many nursing professionals still face serious challenges in the performance of their duties ${ }^{(2,4)}$. Exhaustive routines, high demands for work and productivity, stress, precariousness in the cares rendered, lack of dialogue, banalization of death, and bureaucracy, among other characteristics, may influence the way nursing cares are carried out, resulting in feelings of impotence toward situations and apparent negligence to users ${ }^{(8)}$. This may cause discomfort and suffering, without commonly identifying it as moral distress.

Problems that are difficult to deal with and to solve and that involve complex relations of power and authority add a subjective dimension to the nursing work, and they are complicated even more by the lack of dialogue and communication, common characteristics among the members of the teams. In general, most studies suggest that moral distress makes a big impact on the lives of the nursing professionals. Qualitatively, feelings of anger and sadness are the most cited ones in the literature as psychosocial effects caused by moral distress - introspection being the main characteristic ${ }^{(10)}$.

One identified problem concerns the conflict between experienced and newly-graduated professionals. Education and experience are not always beneficial to professionals, causing, occasionally, the hampering of moral sensibility of more experienced professionals. On its turn, the current nursing, by focusing on clinical and biomedical aspects, may inhibit the personal growth of undergraduates, bringing out difficulties of moral sensibility to newlygraduated ones $^{(1)}$.

These difficulties may make the professional away from the user, ending up with fragilities in his treatment. Two situations may emerge for nursing workers facing moral distress: a very common response of user's defense, which can also cause frustrations to the professionals toward the consequences of their actions; or responses related to impotence, demoralization, helplessness, desperation, anger, affliction and guilt for the failure related to what seems to be expected from the nurse ${ }^{(11)}$.

Moral distress may make nursing professionals trivialize situations, denying possible damages and harms that can be caused in the user and this may favor the abandonment of professional principles in consequence of fear, conveniences or self-preservation. For being a singular individual, different from everyone else, each worker can perceive differently the situations in his life. Nowadays, it is discussed whether moral distress would be an inability to act in situations in which there seems to be only one possibility of action or a discomfort related to the moral subjectivity of professionals ${ }^{(12)}$, which could be associated with the necessity of exercising advocacy of the user.

\section{ADVOCACY OF USER: A CONCEPT TO BE RESCUED}

The main role of nursing, related to user's care and defense of his interests, evinces in its essence a direct relation with morals, thus being possible to verify, through advocacy of user, the fundamental activity of nursing, which, on the other hand, may cause moral distress when the nursing professional is unable to perform this role in way that satisfies his ideals ${ }^{(12)}$.

Although advocacy is not an exclusive attribute of nursing, it is clearly a role that deserves great attention. This term has its definition in the origin of the term advocate - the one who assists, defends or judges another person. In nursing, it is translated as the communication of bad news in an adequate manner, the protection of interests, the construction of more equitable relationships, and the preservation of the user's autonomy ${ }^{(13)}$.

It can be also understood as a response to the problems in the health system and to the disparities caused by these problems. Although it is formulated in terms of call of duty of each professional with the users, defense must also include social and political activism ${ }^{(14)}$.

Still, it can be defined as the users' voice, as a guideline toward the use of specialized knowledge by nursing professionals, as a way of facing the various challenges imposed by the health structures and their power relations, as a way of qualifying users for their self-care, and for intervening in the communication failures between users and health professionals ${ }^{(13)}$.

Since the creation of the term user's advocate, in the 1980 's ${ }^{(15)}$, nursing has been seen as ideal profession to assume this role because of its close relationship with the user and the managing functions assumed by this profession ${ }^{(16)}$. Advocacy seems to have a close relation with power, and it can be seen as a motivational construct for nursing, enabling the facing of the physical and social demands of the health environments ${ }^{(17)}$.

Situations of moral distress reinforce the necessity of the nurse's performance as user's advocate, mainly because of the nature of the work carried out by this professional. It is perceived as constituent parts of users' advocacy the reinforcement of their autonomy, construction of relationships of therapeutic care and improvement of the quality of communication between nursing professionals and users ${ }^{(13)}$.

User's autonomy is an essential part to be defended. By accepting this moral commitment, nursing professionals can show they are in a unique position in health relations, being properly qualified to assist users, and clarify the objectives of their treatments and the making of related health decisions ${ }^{(14)}$. 
One of the themes identified nowadays is the relationship between educational preparation for the role of defender and the ability of defender, that is, the specific professional competence for this job. It is possible to perceive that, although there is a desire related to the defense of users' interests, so often professionals don't have a proper preparation to take their desires ahead, as in the lack of understanding of moral situations or because of personal or technical limitations ${ }^{(14)}$.

Most definitions of advocacy in the health literature present the description of attributes instead of real definitions, and that is a fact that shows the difficulty in making headway in the thematic of advocacy from the theory and intentionality plane, to place it in terms of instituted practice in health systems ${ }^{(16)}$.

\section{REFERRALS AND POSSIBILITIES}

The legacy left by moral distress must be faced with seriousness, since the failure in the intended actions, because of various embarrassments, may result in a definitive behavior in the moral integrity of professionals, leading to incoherence in their values, and endangering future actions. These facts may affect their moral conscience, as demonstrated in the words of a professional when he stated that, after the experience of a certain fact, he would never be the same internally, and that he would bear with him, for the rest of his life, the consequences of the great load of moral distress ${ }^{(18)}$.

The origin of moral dilemmas may have as starting points the moral education of the nursing workers, since the ability to understand a conflictive situation as a moral problem interferes directly in the way of facing and trying to solve problems and the constitution of an autonomous subject becomes an important step. Thus, each human being's life experiences is strongly connected with his moral construction, since the singularity of the facts experienced in the communities determine greatly our values ${ }^{(3)}$.

Nursing needs to assume more effectively the professional and moral responsibilities in order to perform the assistance of the users' needs, and must question, reflect upon, denounce other professional's abusive practices that may be interfering negatively in the care and, consequently, reverberating in bigger moral distress for professionals themselves.

One of the objectives of the care, in its essence, is maintenance of life, besides its promotion and development, and this can be related to the action of listening to, reflecting upon, evaluating and constructing strategies of rehabilitation or healing, along with the characters involved - user and family - according to their cultures and habits ${ }^{(19)}$.

Opposed conceptions, of the health and nursing teams in relation to the user's care, may endanger the nursing professional's moral judgment, since the nursing care to the human being, by having a close relationship with life, cannot be abolished even when the treatment possibilities carried out by the medical team are abandoned(20).

When it concerns to the stagnation often verified toward a situation of moral distress, or the option of resisting and fighting against its effects, adopted by few, we realize that so often the nursing's choice can lean on immobilism and on the lack of resistance. Only a few professionals seem to use strategies of resistance toward moral distress, against a great number of workers that stop exercising their power, whose voices are rarely heard in the communities or in the hallways of health institutions, and this situation may represent nursing's poor exercise of power and a practically null moral resistance toward moral problems ${ }^{(20)}$.

Nursing professionals have to change this panorama and cross the disciplinary and methodological frontiers that seem to cause such attitudes, making their voices be heard publically, which may contribute to the increase of nursing's image. Thus, nursing professionals could create a more productive future even for health cares, since these professionals could promote a continuous integration of the sciences with humanization, rejecting frontiers among specific knowledge and the coldness in relationships ${ }^{(20)}$.

Education in nursing is still a hurdle for the nursing professionals to understand their political importance and how much their knowledge could change reality, and this seems to contribute to the unawareness of the action potential of nursing and the possibility of positive intervention in people's lives. It can no longer be neglected the fact that the classroom is still the most radical environment to start the process of resistance of the nursing professionals, so that they become more critical, reflective and, mainly, with actively reverberating voices in society ${ }^{(17)}$.

Still, it is practically impossible for the nursing professionals to recognize individually the problems that affect them and their users, trying to singly modify them. If the objective of nursing is the care, and this includes the defense of the users and their interests, this goal can only be reached collectively. In order to be effective, defense must be collective, because only in this way nursing itself will be reinforced ${ }^{(14)}$.

\section{CONCLUSION}

Several confrontations are demanded from nursing professionals in their work routine, from those related to the exercise of advocacy of users, those of interest of the health institutions, till those related to desires and personal necessities, so often forgotten or trivialized, related to the exercise of autonomy and power relations not always explicit or perceptible to careless eyes. The recurrence of these situations leads to the need of rethinking nursing and its practices, reviewing relations and their actions in a moral perspective. 
It becomes fundamental to problematize the professional routine in a wide and collective way, trying to reveal how we have constructed and acknowledged ourselves as individuals based on a heteronomous morality who daily mortifies themselves, their desires, and their own indi-

\section{REFERENCES}

1. Range LM, Rotherdam AL. Moral distress among nursing and non-nursing students. Nurs Ethics. 2010;17(2):225-32.

2. Corley MC. Nurse moral distress: a proposed theory and research agenda. Nurs Ethics. 2002;9(6):636-50.

3. Lunardi VL, Barlem ELD, Bulhosa MS, Santos SSC, Lunardi Filho WD, Silveira RS, et al. Moral distress and the ethical dimension in nursing work. Rev Bras Enferm. 2009;62(4):599-63.

4. Ham K. Principled thinking: a comparison of nursing students and experienced nurses. J Contin Educ Nurs. 2004;35(2):66-73.

5. Lützen K, Blom T, Ewalds-Kivist B, Winch S. Moral stress, moral climate and moral sensitivity among psychiatric professionals. Nurs Ethics. 2010;17(2):213-24.

6. Jameton A. Nursing practice: the ethical issues. Englewood Cliffs: Prentice-Hall; 1984.

7. Corley MC, Elswick RK, Gorman M, Clor T. Development and evaluation of moral distress scale. J Adv Nurs. 2001;33(2):250-56.

8. Pauly B, Varcoe C, Storch J, Newton L. Registered Nurses' perceptions of moral distress and ethical climate. Nurs Ethics. 2009;16(5):561-73.

9. Regis LFLV, Porto IS. Basic human needs of nursing professional: situations of (dis)satisfaction at work. Rev Esc Enferm USP [Internet]. 2011 [cited 2011 Nov 22]; 45(2):334-41. Available from: http://www.scielo.br/pdf/reeusp/v45n2/en_v45n2a04.pdf

10. Austin W, Kelecevic J, Goble E, Mekechuk J. An overview of moral distress and the paediatric intensive care team. Nurs Ethics. 2009;16(1):57-68.

11. Ferrell BR. Understanding moral distress of nurses witnessing medically futile care. Oncol Nurs Forum. 2006;33(5):922-30. viduality without even question about the reasons of such options and actions. More than ever it is time to question, after all, what has been supporting the maintenance of a personal attitude that does not express resistance, and does not do what we acknowledge as correct.

12. Hanna DR. The lived experience of moral distress: nurses who assisted with elective abortions. Res Theory Nurs Pract. 2005;19(1):95-124.

13. Hanks RG. Development and testing of an instrument to measure protective nursing advocacy. Nurs Ethics. 2010;17(2):255-67.

14. Mahlin M. Individual patient advocacy, collective responsibility and activism within professional nursing associations. Nurs Ethics. 2010;17(2):247-54.

15. Gadow S. Existential advocacy: philosophical foundation of nursing. In: Spicker SF, Gadow S, editors. Nursing images and ideals: opening dialogue with the humanities. New York: Springer; 1980. p.79-101.

16. Hanks RG. Barriers to nursing advocacy: a concept analysis. Nurs Forum. 2007;42(4):171-7.

17. Vaartio $H$, Leino-Kilpi $H$, Suominent T, Puukka P. Nursing advocacy in procedural pain care. Nurs Ethics. 2009;16(3):34062.

18. Webster GC, Baylis F. Moral residue. In: Rubin SB, Zoloth L, editors. Margin of error: the ethics of mistakes in the practice of medicine. Hagerstown: University Publishing Group; 2000. p. 217-30.

19. Colliére MF. Promover a vida: da prática das mulheres de virtude aos cuidados de enfermagem. Lisboa: LIDEL; 1999.

20. Kagan NPN. Historical voices of resistance: crossing boundaries to praxis through documentary filmmaking to the public. Adv Nurs Sci. 2009;32(1):19-32. 